\title{
Activities of various cobalamins for Euglena gracilis with reference to vitamin $B_{12}$ assay with Euglena
}

\author{
J. F. ADAMS AND FIONA McEWAN \\ From the Southern General Hospital, Glasgow, Scotland
}

SYNOPSIS Coenzyme $\mathbf{B}_{\mathbf{1 2}}$ and methylcobalamin in water are less active in promoting growth of Euglena gracilis $\mathbf{Z}$ strain than the same concentrations of cyanocobalamin and hydroxocobalamin which are equally active. When bound to human serum or human liver homogenate, however, the activities of these four cobalamins do not differ significantly with one exception. The results suggest that the Euglena assay using cyanocobalamin standards is not satisfactory for quantitation of coenzyme $B_{12}$ and methylcobalamin in water but acceptable when coenzyme $B_{12}$ and methylcobalamin are bound to serum or liver. Sulphitocobalamin in water is as active as cyanocobalamin and hydroxocobalamin but nitritocobalamin is less active. Factor B, the monocarboxylic acids of cyanocobalamin and hydroxocobalamin, and the dicarboxylic acid of cyanocobalamin in water were inactive.

The measurement of the 'vitamin $\mathbf{P}_{13}$ ' concentration in tissues by microbiological assay using Euglena gracilis is a widely used procedure. Euglena gracilis variant bacillaris was used by Hutner, Provasoli, Stokstad, Hoffman, Belt, Franklin, and Jukes (1949) and by Ross (1950 and 1952) who described techniques applicable to clinical material and the $Z$ strain was used by Hutner, Bach, and Ross (1956). Previous studies of the growth-promoting effects of cobalamins and other substances for Euglena gracilis, summarized by Smith (1965), preceded the discovery of the roles of methylcobalamin and coenzyme $\mathbf{B}_{12}$ in human metabolism (Toohey and Barker, 1961; Lindstrand and Ståhlberg, 1963; Ståhlberg, Radner, and Nordén, 1967), and as the activity of these cobalamins and certain analogues for Euglena gracilis Z strain had not been studied, it seemed desirable to do so.

\section{Materials and Methods}

In all studies the assay methodology was essentially that of Hutner et al (1956) using Euglena gracilis $Z$ strain and commercially available medium (Difco Laboratories Inc.). The incubation period was five days at a bath temperature of $29^{\circ} \mathrm{C}$ and illumination by two 'warm white' 30 watt fluorescent tubes. Samples were assayed in triplicate and the optical density of the cultures was measured in a Unicam SP 300 photometer using an Ilford 204 filter and cells with an optical path of $2.5 \mathrm{~mm}$.

Received for publication 18 June 1970.
Solutions of cyanocobalamin, hydroxocobalamin, coenzyme $B_{12}$, methylcobalamin, sulphitocobalamin, nitritocobalamin, factor B, and the 'red acids'the monocarboxylic acid of cyanocobalamin, the monocarboxylic acid of hydroxocobalamin, and the dicarboxylic acid of cyanocobalamin-were made available in known concentration by $\mathrm{Dr}$ L. Mervyn of Glaxo Ltd. Various batches of cyanocobalamin, hydroxocobalamin, methylcobalamin, and coenzyme $\mathbf{B}_{12}$ were used, the concentrations being confirmed by absorption spectrometry with a Unicam SP 800 spectrophotometer. Unless otherwise stated, solutions were stored at $+4^{\circ} \mathrm{C}$ and all manipulations except those immediately preceding microbiological assay were carried out in a dim red light.

Initially all samples were assayed on at least three occasions in final concentrations of $1 \cdot 25,2 \cdot 5,5$, $10,15,25$, and $50 \mu \mu \mathrm{g} / \mathrm{ml}$ and the values compared to those obtained with cyanocobalamin at the same final concentrations. In view of the results further studies were undertaken as follows: (1) the effect of increasing concentrations of factor $B$ and the 'red acids'; (2) repeated assays of aqueous solutions of coenzyme $B_{12}$ and methylcobalamin in concentrations of $750 \mu \mu \mathrm{g} / \mathrm{ml}$ and $375 \mu \mu \mathrm{g} / \mathrm{ml}$; and (3) repeated assays of cyanocobalamin, hydroxocobalamin, methylcobalamin, and coenzyme $B_{12}$ in aqueous solution and bound to pools of serum and human liver homogenate. For the last-named study materials were prepared in a dim red light at $17^{\circ} \mathrm{C}$ by adding $4,000 \mu \mu \mathrm{g}$ cobalamin in $1 \mathrm{ml}$ 


\begin{tabular}{|c|c|c|}
\hline Test Sample & & $\begin{array}{l}\text { Mean Values and Standard Deviation of } \\
\text { Eight Assays }(\mu \mu \mathrm{g} / \mathrm{ml} \text { from } \\
\text { cyanocobalamin standards })\end{array}$ \\
\hline $\begin{array}{l}\text { Water }(9 \mathrm{ml}) \text { + water }(1 \mathrm{ml}) \\
\text { Water }(9 \mathrm{ml}) \text { + cyanocobalamin } \\
\text { Water }(9 \mathrm{ml}) \text { + hydroxocobalamin } \\
\text { Water }(9 \mathrm{ml}) \text { + methylcobalamin } \\
\text { Water }(9 \mathrm{ml}) \text { + coenzyme } B_{12}\end{array}$ & $\begin{array}{l}(1 \mathrm{ml}-4,000 \mu \mu \mathrm{g}) \\
(1 \mathrm{ml}-4,000 \mu \mu \mathrm{g}) \\
(1 \mathrm{ml}-4,000 \mu \mu \mathrm{g}) \\
(1 \mathrm{ml}-4,000 \mu \mathrm{g})\end{array}$ & $\begin{array}{l}2 \cdot 5 \\
458(62 \cdot 5) \\
392(65 \cdot 5) \\
293(66 \cdot 2) \\
313(47 \cdot 4)\end{array}$ \\
\hline $\begin{array}{l}\text { Pool serum }(9 \mathrm{ml}) \\
\text { Pool serum + water }(1 \mathrm{ml}) \\
\text { Pool serum + cyanocobalamin } \\
\text { Pool serum + hydroxocobalamin } \\
\text { Pool serum + methylcobalamin } \\
\text { Pool serum + coenzyme } B_{12}\end{array}$ & $\begin{array}{l}(1 \mathrm{ml}-4,000 \mu \mu \mathrm{g}) \\
(1 \mathrm{ml}-4,000 \mu \mu \mathrm{g}) \\
(1 \mathrm{ml}-4,000 \mu \mu \mathrm{g}) \\
(1 \mathrm{ml}-4,000 \mu \mathrm{g})\end{array}$ & $\begin{array}{l}357(64 \cdot 0) \\
527(89 \cdot 3) \\
538(108 \cdot 6) \\
507(111 \cdot 4) \\
504(92 \cdot 9)\end{array}$ \\
\hline $\begin{array}{l}\text { Pool liver homogenate }(9 \mathrm{ml}) \\
\text { Pool liver + water }(1 \mathrm{ml}) \\
\text { Pool liver + cyanocobalamin } \\
\text { Pool liver + hydroxocobalamin } \\
\text { Pool liver + methylcobalamin } \\
\text { Pool liver + coenzyme } \mathbf{B}_{12}\end{array}$ & $\begin{array}{l}(1 \mathrm{ml}-4,000 \mu \mu \mathrm{g}) \\
(1 \mathrm{ml}-4,000 \mu \mu \mathrm{g}) \\
(1 \mathrm{ml}-4,000 \mu \mu \mathrm{g}) \\
(1 \mathrm{ml}-4,000 \mu \mu \mathrm{g})\end{array}$ & $\begin{array}{l}397(39.3) \\
842(219 \cdot 2) \\
720(78 \cdot 6) \\
776(80 \cdot 0) \\
710(95 \cdot 9)\end{array}$ \\
\hline
\end{tabular}

Table I Constitution of test samples and mean values and standard deviation from eight assays ${ }^{1}$

${ }^{1}$ S eparate aliquot of each test sample and appropriate cyanocobalamin standards were assayed on each occasion.

water to $9 \mathrm{ml}$ pooled tissue, and after mixing for $15 \mathrm{~min}$, dispensing in aliquots of $1.25 \mathrm{ml}$ in plastic tubes; dilutions of the same batch of cyanocobalamin used in the preparation of test samples were prepared for use as standard at the same time. Batches of standards, blanks, and test samples were then incubated at $17^{\circ} \mathrm{C}$ for 12 hours, exposed to daylight for 20 minutes, and then stored at $-20^{\circ} \mathrm{C}$ in the dark until assayed. Each batch was assayed once and then discarded. Assays were performed at intervals of one week. The test samples were assayed at dilutions of $1: 20$ and the activity was compared to that of the cyanocobalamin standards which, after final dilution at $1 \cdot 20$, had values of $2 \cdot 5,5,10,15,20$, $25,30,35,40,45,50$, and $60 \mu \mu \mathrm{g} / \mathrm{ml}$. The serum pool was prepared from blood obtained from eight healthy subjects and was stored in glassware at $-20^{\circ} \mathrm{C}$. The liver homogenate pool was prepared from equal volumes of liver homogenates $(1 \mathrm{~g}$ per $1,000 \mathrm{ml})$, the tissues being obtained at necropsy on eight patients who had died of cardiac or cerebrovascular disease and had not received antibiotics.

\section{Results}

The activities of aqueous solutions of hydroxocobalamin and sulphitocobalamin were always the same as those of similar concentrations of cyanocobalamin in the range 1.25 to $50 \mu \mu \mathrm{g} / \mathrm{ml}$ as judged by the optical densities of the cultures. Methylcobalamin, coenzyme $B_{12}$, and nitritocobalamin were always less active than corresponding concentrations of cyanocobalamin in the range 1.25 to $50 \mu \mu \mathrm{g} / \mathrm{ml}$ and their activities were about $65 \%$ that of cyanoco- $\stackrel{2}{2}$ balamin.

Factor $B$ and the red acids were inactive at low concentrations. At a concentration of $10,000 \mu \mu \mathrm{g} / \mathrm{ml}$ factor B had an activity equal to cyanocobalamin $10 \mu \mu \mathrm{g} / \mathrm{ml}$ and the monocarboxylic acid of cyanocobalamin at $100,000 \mu \mu \mathrm{g} / \mathrm{ml}$ was as active as cyanocobalamin $50 \mu \mu \mathrm{g} / \mathrm{ml}$. The monocarboxylic acid of hydroxocobalamin and the dicarboxylic acid of cyanocobalamin were inactive at concentrations up to and including $200,000 \mu \mu \mathrm{g} / \mathrm{ml}$.

An aqueous solution of coenzyme $B_{12} 750 \mu \mu \mathrm{g} / \mathrm{ml}$ assayed on six occasions gave a mean value of 483 $\mu \mu \mathrm{g} / \mathrm{ml}$ (standard deviation 81.4) as expressed from the cyanocobalamin standards and a solution of $375 \mu \mu \mathrm{g} / \mathrm{ml}$ a value of $256 \mu \mu \mathrm{g} / \mathrm{ml}$ (standard deviation 65.0 ) the relative activities being $64 \%$ and $68 \%$. Similarly, six assays of methylcobalamin $750 \mu \mu \mathrm{g} / \mathrm{ml}$ gave a mean value of $544 \mu \mu \mathrm{g} / \mathrm{ml}$ (standard deviation 123) an activity of $72 \%$ and methylcobalamin $375 \mu \mu \mathrm{g} / \mathrm{ml}$ a mean value of $232 \mu \mu \mathrm{g} / \mathrm{ml}$ (standard deviation 96 ) an activity of $62 \%$.

The results for eight assays of cyanocobalamin, $N$ hydroxocobalamin, methylcobalamin, and coenzyme $N$ $B_{12}$ in aqueous solution and bound to pooled tissues 슬 are summarized in Table I. Analysis of the results by the Wilcoxon test ( 2 tail) showed significant differences in the results from aqueous solutions of cyanocobalamin and coenzyme $B_{12}(P<0.01)$, cyanocobalamin and methylcobalamin $(P<0.01)$, hydroxocobalamin and coenzyme $B_{12}(P<0.01)$, hydroxocobalamin and methylcobalamin $(P<0.01)$, and in the results from serum-bound hydroxoco- $\frac{?}{\mathbb{D}}$ balamin and serum-bound coenzyme $B_{12}(P<0.02)$. 


\section{Discussion}

The most interesting results are those relating to the 'physiological cobalamins'-coenzyme $\mathbf{B}_{12}$, methylcobalamin, hydroxocobalamin, and cyanocobalamin. Photolysis of coenzyme $B_{12}$ and methylcobalamin leads to the formation of hydroxocobalamin which was found by Robbins, Hervey, and Stebbins (1950) to be as active as cyanocobalamin for Euglena gracilis var. bacillaris and confirmed for the $Z$ strain in this study. The results of assays of several batches of coenzyme $B_{12}$ and methylcobalamin of known, that is spectrophotometric concentration, were therefore unexpected. Further enquiries were indicated because these results raised the suspicion that values obtained by Euglena assay of tissues were underestimates. Because of the considerable interassay variation (see Ross, Hutner, and Bach, 1957; Anderson, 1964) repetitive assays were necessary. The results formalized statistically the previous finding that coenzyme $\mathbf{B}_{12}$ and methylcobalamin in water have an activity which is significantly inferior to similar concentrations of cyanocobalamin and hydroxocobalamin. In addition it is clear that this inferiority is abolished when the cobalamins are bound to serum or liver homogenate, the sole exception being serum-bound coenzyme and serum-bound hydroxocobalamin. Any explanation of the results must take into account the fact that hydroxocobalamin is a product of photolysis of coenzyme $B_{12}$ and methylcobalamin, and this suggests that other products of photolysis act as inhibitors to the growth of Euglena unless tissues are also present. Treatment of coenzyme $B_{12}$ in water with potassium cyanide, before and after photolysis, by prolonged photolysis in aerobic conditions, and by autoclaving at $15 \mathrm{lb}$ for up to 30 minutes did not affect the activity, and attempts at isolating an inhibitor from solutions of photolysed coenzyme $B_{12}$ were unsuccessful.

From the practical aspect it is clear that quantitation of solutions of coenzyme $\mathbf{B}_{\mathbf{1 2}}$ and methylcobalamin in water by Euglena assay using cyanocobalamin or hydroxocobalamin standards will result in a significant underestimate of the true concentration. The absence of significant differences, with one exception, between cobalamins bound to serum or liver homogenate does not necessarily mean, however, that quantitation of serum or liver-bound coenzyme $\mathbf{B}_{12}$ and methylcobalamin can be achieved with cyanocobalamin or hydroxocobalamin standards. Taking the mean values for cyanocobalamin or hydroxocobalamin, pool serum, and pool liver homogenate (Table I) the recovery rates for cyanocobalamin and hydroxocobalamin added to liver are $98 \%$ and $91 \%$ respectively which give rise to confidence. With pool serum, however, the recovery rates for cyanocobalamin and hydroxocobalamin are $65 \%$ and $72 \%$. Such low rates give rise to doubts about the quantitation of serum-bound vitamin $B_{12}$ but may, however, simply be manifestations of the inhibitory effect of serum on Euglena growth (Anderson, 1964).

The use of the conventional terms for concentration of cobalamins, that is mass of solute in volume of solution, was convenient in this study. On occasion this convention may result in misleading results and it is relevant to point out that calculation of the results in terms of molarity does not affect the conclusions.

There is no evidence that nitritocobalamin, factor $B$, and the three 'red acids' tested play a part in vitamin $\mathbf{B}_{12}$ metabolism in man and the results are of little practical interest. We ascribe the trivia! activities of the red acids and factor $B$ as due to traces of cyanocobalamin and the results for factor B accord with those found by Coates and Kon (1957) using Euglena gracilis var. bacillaris. It seems inherently more likely that the lack of B activity of factor B and the 'red acids' tested is due to considerable differences in structure than to the presence of inhibitors.

We are grateful to Dr L. Mervyn, to Dr E. H. Hastings, and to Dr W.S.T. Thomson, for assistance. We acknowledge with thanks grants from the Secretary of State for Scotland and the Scottish Hospital Endowment Research Trust.

\section{References}

Anderson, B. B. (1964). Investigations into the Euglena method for the assay of vitamin $B_{12}$ in serum. J. clin. Path., 17, 14-26.

Coates, M. E., and Kon, S. K. (1957). Biological and microbiological activities of purine and benziminazole analogues of vitamin $B_{12}$. In Vitamin $B_{12}$ und Intrinsic Faktor, edited by H. C. Heinrich, pp. 72-82. Enke, Stuttgart

Hutner, S. H., Bach, M. K. and Ross, G. I. M. (1956). A sugarcontaining basal medium for vitamin $\mathrm{B}_{12}$ assay with Euglena: application to body fluids. J. Protozool., 3, 101-112.

Hutner, S. H., Provasoli, L., Stokstad, E. L. R., Hoffmann, C. E. Belt, M. , Franklin, A. L., and Jukes, T. H. (1949). Assay of antipernicious anemia factor with Euglena. Proc. Soc. exp. Biol. $(N . Y), 70,.118-120$.

Lindstrand, K., and Ståhlberg, K. G. (1963). On vitamin $B_{12}$ forms in human plasma. Actamed. scand., 174, 665-669.

Robbins, W. J., Hervey, A. a nd Stebbins, M. E. (1960). Studies on Euglena and vitamin $B_{12}$. Bull. Torrey bot. Club, 77, 423-441.

Ross, G. I. M. (1950). Vitamin $B_{12}$ assay in body fluids. Nature (Lond.), 166, 270-271.

Ross, G. I. M. (1952). Vitamin $\mathbf{B}_{12}$ assay in body fluids using Euglena gracilis. J. clin. Path., 5, 250-256.

Ross, G. I. M., Hutner, S. H., and Bach, M. K. (1957). An improved Euglena method of vitamin $\mathrm{B}_{12}$ assay. In Vitamin $\mathrm{B}_{12}$ und Intrinsic Faktor, edited by H. C. Heinrich, pp. 305-310. Enke, Stuttgart.

Smith, E. L. (1965). Vitamin $B_{13}$, 3rd ed, pp. 84-86 and 106-110. Methuen, London.

Ståhlberg, K. G., Radner, S., and Nordén, A. (1967). Liver B in subjects with and without $B_{12}$ deficiency: a quantitative and qualitative study. Scand. J. Haemat., 4, 312-320.

Toohey, J. I., and Barker, H. A. (1961). Isolation of coenzyme $B_{1,}$ from liver. J. Biol. Chem., 236, 560-563. 